\title{
Tinjauan Yuridis Tentang Penerapan Hukuman Terhadap Pelaku Tindak Pidana Penganiayaan Yang Menyebabkan Luka Berat
}

\author{
Fajar Padly ${ }^{1}$ \\ ${ }^{1}$ Fakultas Hukum Universitas Muhammadiyah Tapanuli Selatan, Sumatera Utara
}

\begin{abstract}
ABSTRAK
Tulisan ini bertujuan untuk adalah untuk mengetahui penerapan hukuman terhadap pelaku tindak pidana penganiayaan yang menyebabkan luka berat di Pengadilan Negeri Padangsidimpuan dan untuk mengetahui pertimbangan Hakim dalam menjatuhkan hukuman terhadap pelaku tindak pidana penganiayaan yang mengakibatkan luka berat. Metode penelitian yang penulis gunakan dalam penulisan penelitian ini adalah penelitian normatif yang menggunakan sumber-sumber data skunder dan berupa peraturan Perundangundangan, serta Putusan Pengadilan Negeri Padangsidimpuan yang telah berkekuatan hukum tetap yang maksudnya adalah penelitian yang dilakukan dengan hasil wawancara penulis dengan responden dan juga melakukan penelitian terhadap data-data maupun berkas-berkas yang berkaitan dengan penelitian ini dengan cara melakukan Penelitian Lapangan (Library Research) dan Penelitian Kepustakaan (Field Research). Teknik atau alat yang penulis gunakan dalam mengumpulkan data baik dilapangan maupun dalam melakukan wawancara dengan responden yang ditemui penulis serta data yang diambil dari dokumen yang berkaitan dengan permasalahan yang dirumuskan dalam penelitian ini yaitu Interview.Kesimpulan penelitian ini untuk mengetahui penerapan hukuman terhadap pelaku tindak pidana penganiayaan yang menyebabkan luka berat disidang Pengadilan Negeri Padangsidempuan adalah harus berdasarkan fakta-fakta di persidangan dari keterangan saksi-saksi, keterangan terdakwa, alat bukti, dan alat bukti surat, menurut penulis Jaksa Penuntut Umum telah tepat dalam menetapkan dakwaan dan terdakwa terbukti telah melakukan tindak pidana penganiayaan yang menyebabkan luka berat yang memenuhi unsur-unsur sebagaimana yang terdapat dalam Pasal 351 ayat (1) Kitab Undang-undang Hukum Pidana dimana terakwa Marhan Siregar telah dijatuhi dengan hukum penjara 2 (dua) tahun.
\end{abstract}

Kata-kata Kunci: Tinjauan Yuridis, Tindak Pidana, Penganiayaan

\section{PENDAHULUAN}

Negara Kesatuan Republik Indonesia merupakan salah satu Negara besar yang sangat mengedepankan ketentuan hukum yang berlaku.Aturan hukum positif yang berlaku di Indonesia jelas menjadi komponen penting dalam membangun kehidupan yang aman, tentram dan damai.Salah satu bidang hukum dalam rangka menjaga ketertiban dan keamanan warga Negara Indonesia sendiri yaitu hukum pidana. 
Hukum Pidana di Indonesia menjadi salah satu pedoman yang sangat penting dalam mewujudkan suatu keadilan.Kitab Undang-undang Hukum Pidana (KUHP) adalah dasar yang kuat dalam rangka menentukan perbuatan yang terlarang dan memiliki sanksi yang tegas bagi yang melanggarnya.Ketentuan umum, kejahatan hingga dengan pelanggaran menjadi tiga bagian penting yang termuat dalam KUHP.

Kejahatan merupakan perbuatan yang menyalahi etika dan moral sehingga dari suatu kejahatan yang dilakukan seseorang maka tentu perbuatan tersebut memiliki dampak yang sangat merugikan orang lain selaku subjek hukum. Terdapat berbagai tindak kejahatan yang dipandang sebagai suatu perbuatan pidana.Meskipun sebagaian besar tindak kejahatan yang telah termuat dan di atur dalam Kitab Undang-undang Hukum Pidana (KUHP) yang secara tegas memiliki ancaman sanksi pidana, kejahatan menjadi suatu bentuk sikap manusia yang harus kita kawal bersama dalam membangun kehidupan bermasyarakat yang tertib dan aman. Salah satu bentuk kejahatan yang seringkali terjadi disekitar kita yakni kejahatan dalam bentuk kekerasan seperti penganiyaan.Maraknya tindakan penganiayaan yang kita lihat dari berbagai sumber menjadi pertanda bahwa hal tersebut tidak lepas dari perilaku masyarakat yang kurang terkontrol baik itu yang dikarenakan rendahnya tingkat pendidikan dan pengaruh lingkungan pergaulan yang kurang baik.Perselisihan baik secara personal ataupun kelompok dapat menjadi suatu faktor yang dapat mengundang terjadinya tindak kekerasan yang berujung pada penganiayaan.

Menurut Soesilo (1993:244) salah satu tindak pidana yang sering terjadi adalah penganiayaan. Oleh karena itu tindak pidana penganiayaan merupakan perbuatan yang bertentangan dengan norma hukum sehingga dilarang oleh undang-undang. Dalam Pasal 351 KUHP dirumuskan sebagai berikut :

1. Penganiayaan diancam dengan pidana penjara paling lama dua tahun delapan bulan atau pidana denda paling banyak empat ribu lima ratus rupiah,

2. Jika perbuatan mengakibatkan luka-luka berat, yang bersalah diancam dengan pidana penjara paling lama lima tahun

3. Jika mengakibatkan mati, diancam dengan pidana penjara paling lama tujuh tahun

4. Dengan penganiayaan disamakan sengaja merusak kesehatan

5. Percobaan untuk melakukan kejahatan ini tidak dipidana.

Apabila akibat dari penganiayaan mengakibatkan luka berat maka perbuatan itu benar-benar merugikan korban yang harus menderita seumur hidup.Karena begitu besar kerugian yang dialami oleh korban maka menjadi kewajiban aparat penegak hukum untuk menangani tindak pidana penganiayaan yang menyebabkan luka berat dengan serius dan yang seadil-adilnya. 
Kejaksaan sebagai salah satu aparat penegak hukum yang mempunyai tugas utama dalam penegakan hukum sebagai Penuntut Umum dan mempunyai kewajiban untuk mengajukan penuntutan terhadap terdakwa yang melakukan tindak pidana penganiayaan yang menyebabkan luka berat. Dalam Pasal 1 angka 6 huruf a dan b dinyatakan bahwa:

a. Jaksa adalah pejabat yang diberi wewenang oleh Undang-undang ini bertindak sebagai penuntut umum serta melaksanakan putusan pengadilan yang telah memperoleh kekuatan hukum tetap.

b. Dinyatakan bahwa penuntut umum adalah jaksa yang diberi wewenang oleh undangundang untuk melakukan penuntutan dan melaksanakan penetapan hakim.

Dalam Pasal 1 ayat 7 Kitab Undang-undang Hukum Acara Pidana dinyatakan bahwa: "Penuntutan adalah tindakan penuntut umum untuk melimpahkan perkara pidana ke pengadilan negeri yang berwenang dalam hal dan menurut cara yang diatur Undang-undang ini dengan permintaan supaya diperiksa dan diputus oleh hakim di sidang pengadilan.

Menurut Van Hamel(1979:75) tentang Strafbaar sebagaimana yang dikutip dalam buku karangan Satochid Kartanegara adalah sebagai berikut : "Strafbaar sama dengan sifat perbuatan yang mempunyai sifat yang dapat di hukum”. Selanjutnya Satichid Kartanegara yang mengemukakan Feit dalam Strafbaar Feit adalah sebagai berikut : "Feit dinyatakan dalam Undang-undang.

\section{PEMBAHASAN}

Penganiayaan Berat Sebagai Tindak Pidana Dalam Kitab Undang-undang Hukum Pidana. Sebagaimana di dalam Undang-undang tidak memberi ketentuan apakah apakah yang diartikan dengan penganiayaan (mishandeling) itu sendiri menurut menurut yuriprudensi, maka yang diartikan dengan pengniayaan yaitu sengaja mengakibatkan perasaan tidak enak seperti (penderita), rasa sakit (pilu) atau luka, menurut Pasal 351 ayat 4 KUHP (Kitab Undang-Undang Pidana) masuk pula dalam pengertian penganiayaan adalah sengaja merusak kesehatan orang seperti yang dikemukakan oleh Hakim Pengadilan Negeri Padangsidimpuan Aries Kata Ginting. SH yaitu :

1. Perasaan tidak enak: misalnya mendorong orang ke kali sehingga basah.

2. Rasa sakit: misalnya mencubit, mendupak, memukul, menempeleng dan sebagainya.

3. Luka misalnya mengiris, memotong, menusuk dengan pisau dan sebagainya.

Dengan demikian berdasarkan pendapat Hakim tersebut di atas yang dinamakan ”penganiayaan berat” supaya dapat dikenakan pasal ini, maka niat membuat harus ditujukan 
pada "melukai berat" artinya luka berat harus dimaksud oleh si pembuat, apabila tidak dimaksud dan luka berat itu hanya merupakan akibat saja, maka perbuatan itu masuk ”penganiayaan biasa yang berakibat luka berat”, kemudian apa yang dimaksud dengan luka berat dan luka parah, Pasal 90 Kitab Undang-undang Hukum Pidana memberi keterangan bahwa yang dimaksud dengan luka berat yaitu :

1. Jatuh sakit atau mendapat luka yang tidak memberi harapan akan sembuh sama sekali Jatau yang menimbulkan bahaya maut.

2. Tidak mampu terus menerus untk menjalankan tugas jabatan atau mencari pekerjaan.

3. Kehilangan salah satu panca indera.

4. Mendapat cacat berat.

5. Menderita sakit lumpuh.

6. Terganggunya daya pikir selama 4 minggu lebih.

7. Gugurnya atau matinya kandungan seorang perempuan

Dengan berdasarkan penjelasan tersebut di atas sebagaimana yang terdapat dalam Putusan Pengadilan Negeri Padangsidimpuan Nomor, 236/Pid.B/2015/PN.PSP yang dilakukan terdakwa Marhan Siregar telah melakukan tindak pidana penganiayaan yang menyebabkan luka luka berat terhada saksi Ahmad Yani Harahap yang berarti dimaksud disini yang menyebabkan luka berat itu adalah sepert contoh dibawah ini :

1. Penyakit atau luka yang tidak boleh diharapkan akan sembuh lagi dengan sempurna atau dapat mendatangkan maut. Jadi luka atau sakit bagaimana besarnya, jika dapat sembuh kembali dengan sempurna dan tidak mendatangkan bahaya maut(tatib atau dokter yang bisa menerangkan hal ini) itu bukan luka berat.

2. Terus-menerus tidak cakap lagi melakukan jabatan atau pekerjaan, kalau hanya berat sementara saja bolehnya tidak cakap melakukan pekerjaannya, hal itu tidak termasuk luka berat. Penyanyi misalnya jika rusak kerongkongnya,sehingga tidak dapat menyanyi lagi selamanyaitu termasuk luka berat.

3. Tidak lagi memakai (kehilangan) salah satu panca indera, penglihatan, penciuman, pendengaran, rasa lidah dan rasa sakit.

4. Lumpuh artinya tidak bisa menggerakkan baddan.

5. Berubah pikiran lebih dari 4 minggu, pikiran bisa terganggu, kacau, tidak memikir secara normal.

6. Menggugurkan atau membunuh bakal anak dalam kandungan

Penerapan Hukum Pidana Materiil Terhadap Tindak Pidana Penganiayaan Yang Menyebabkan Luka. 
Delik penganiyaan yang menyebabkan luka berat sebagaimana yang dilakukan oleh terdakwa Marhan Siregar dalam kasus Putusan Pengadilan Negeri Padangsidimpuan Nomor, 236/Pid.B/2015/PN.PSP yang kemudian telah diputuskan sehingga pelaku tindak pidana diputus bersalah oleh Majelis Hakim dengan menjatuhkan hukuman kepada terdakwa Marhan Siregar pidana penjara selama 2 (dua) tahun

Dimana perbuatan terdakwa sebelum di dijatuhi dengan hukuman oleh Hakim haruslah dibuktikan terlebih dahulu dalam proses persidangan, hal inilah kemudian menjadi tugas Jaksa Penuntut Umum dalam membuktikan bersalah terdakwa yang kemudian akan dinilai oleh Hakim sebagaimana yang dikemukakan oleh Hakim Pengadilan Negeri Padangsidimpuan Aries Kata Ginting. SH, yang mengatakan bahwa untuk membuktikan seorang terdakwa bersalah atau tidak harus berdasarkan kepada alat-alat bukti seperti yang terdapat di dalam Pasal 184 Kitab Undang-undang Hukum Pidana dibawah ini :
a. Keterangan saksi
b. Keterangan ahli
c. Surat
d. Petunjuk
e. Keterangan terdakwa

Berdasarkan pemeriksaan dalam kasus ini, majelis Hakim kemudian menyatakan terdakwa Marhan Siregar telah terbukti secara sah dan meyakinkan melakukan penganiayaan yang menyebabkan luka berat terhadap saksi Ahmad Yani Harahap. Delik penganiyaan yang dilakukan oleh terdakwa Marhan Siregar terhadap saksi korban Ahmad Yani Harahap telah menyebabkan adanya luka sayatan dikepala belakang tepatnya di belakang telinga sebelah kiri sepanjang $\pm 10 \mathrm{Cm}$, luka sayatan pada bahu kiri panjang $\pm 3 \mathrm{Cm}$ dan luka gores pada punggung sebelah kiri panjang $\pm 2 \mathrm{Cm}$, berdasarkan Visum Et Repertum Projustita RSUD No. 440/49/VL/II/2015 tanggal 28 Februari 2015 an. Ahmad Yani Harahap yang ditanda tangani oleh dr. Indah Sari Harahap

Sebagaimana diketahui bahwa dalam kasus ini, Jaksa Penuntut Umum mendakwa terdakwa dengan surat dakwaan pertama, Jaksa Penuntut Umum menggunakan bahwa terdakwa telah didakwa oleh Penuntut Umum dengan Dakwaan Alternatif yaitu Pertama Pasal 338 KUHP Jo Pasal 53 ayat (1) KUHP, Kedua Pasal 351 ayat (2) KUHP dan Ketiga Pasal 351 ayat (1) Kitab Undang-undang Hukum Pidana

Berdasarkan fakta-fakta di persidangan dari keterangan saksi-saksi, keterangan Terdakwa, alat bukti, dan alat bukti surat, menurut penulis Jaksa Penuntut Umum telah tepat dalam menetapkan dakwaan dan terdakwa terbukti telah melakukan tindak pidana penganiayaan 
yang menyebabkan luka berat yang memenuhi unsur-unsur sebagaimana yang terdapat dalam tuntutan Penuntut Umum Pasal 352 ayat (2) yang penjelasannya sebagai berikut:

1. Unsur Barang siapa :

Menimbang bahwa yang dimaksud dengan barang siapa adalah setiap orang atau subjek hukum yang melakukan suatu tindak pidana yang dalam hal ini dilakukan oleh terdakwa yang kami ajukan dalam persidangan ini sebagai terdakwa, yang mana selama pemeriksaan dipersidangan tidak ditemukan alasan-alasan pemaaf atau pembenar terdakwa dalam melakukan perbuatan tersebut sehingga unsur ini telah terpenuhi menurut hokum, maka Hakim pun dapat menjatuhkan hukuman terhadap pelaku tindak pidana penganaaiayaan menyebabkan luka berat sebagaimana yang terdapat dalam Putusan Pengadilan Negeri Padangsidimpuan Nomor, 236/Pid.B/2015/PN.PSP dengan hukuman penjara 2 (dua) tahun

2. Unsur melakukan penganiayaan yang mengakibatkan luka berat Menimbang, sesuai dengan fakta-fakta yang terungkap dalam persidangan sesuai dengan keterangan saksi-saksi dan keterangan terdakwa serta adanya barang bukti, pada hari Rabu tanggal 25 Februari 2015 sekira pukul 19.00 Wib atau setidaktidaknya pada suatu waktu pada Tahun 2015 bertempat di Dusun Panompuan Julu Desa Panompuan Kecamatan Tantom Angkola Timur Kabupaten Tapanuli Selatan, pada hari Rabu tanggal 25 Februari 2015 sekira pukul 19.00 Wib atau setidaktidaknya pada suatu waktu pada Tahun 2015 bertempat di Dusun Panompuan Julu Desa Panompuan Kecamatan Tantom Angkola Timur Kabupaten Tapanuli Selatan dan akibat perbuatan terdakwa tersebut saksi korban mengalami luka-luka dan menjadi terhalang untuk melakukan kegiatan sehari-hari, dengan demikian unsur ini telah terbukti, maka Hakim pun dapat menjatuhkan hukuman terhadap pelaku tindak pidana penganaaiayaan menyebabkan luka berat sebagaimana yang terdapat dalam Putusan Pengadilan Negeri Padangsidimpuan Nomor, 236/Pid.B/2015/PN.PSP dengan hukuman penjara 2 (dua) tahun

Dengan demikian setiap terdakwa yang melakukan tindak pidana seperti dalam Putusan Pengadilan Negeri Padangsidimpuan Nomor, 236/Pid.B/2015/PN.PSP yaitu tindak pidana penganiayaan yang menyebabkan luka berat terdakwa harus mempertanggungjawabakan perbuatannya yang pada dasarnya menjurus kepada pemidanaan pelaku, jika telah melakukan tindak pidana yang memenuhi unsur- unsur yang telah ditentukan dalam Undang-undang.

Dilihat dari sudut terjadinya tindakan yang dilarang, seseorang akan dipertanggungjawabkan atas tindakan-tindakan tersebut, apabila tindakan tersebut melawan hukum serta tidak ada 
alasan pembenar atau peniadaan sifat melawan hukum untuk pidana yang dilakukannya dan dilihat dari sudut kemampuan bertanggungjawab, maka hanya seseorang harus mampu bertanggungjawab yang dapat dipertanggung jawabkan atas perbuatannya serta tidak ada alasan pembenar atau peniadaan sifat melawan hukum untuk pidana yang dilakukannya. Kemudian berdasarkan penjelasan tersebut di atas disini Jaksa Penuntut Umum melakukan dakwaannya dakwaan Alternatif yaitu Pertama melanggar Pasal 338 KUHP Jo Pasal 53 ayat (1) KUHP, Kedua Pasal 351 ayat (2) KUHP dan Ketiga Pasal 351 ayat (1).

Tujuan Jaksa Penuntut umum menggunakan surat dakwaan Alternatif yaitu Pertama melanggar Pasal 338 KUHP Jo Pasal 53 ayat (1) KUHP, Kedua Pasal 351 ayat (2) KUHP dan Ketiga Pasal 351 ayat (1) Kitab Undang-undang Hukum Pidana. ini yakni agar dari serangkaian perbuatan yang dilakukan oleh pelaku terhadap saksi korban dapat dijerat dengan sanski pidana yang tegas, sehingga pelaku tidak lagi dapat lepas dari pertanggungjawaban pidana atas perbuatan pidana yang telah dilakukan olehnya

Dengan demikian sebagaimana dalam perkara pidana 236/Pid.B/2015/PN.PSP dari uraian posisi kasus sebagaimana yang telah dijelaskan di atas, dalam kasus ini majelis Hakim lebih memilih untuk menjerat terdakwa Marhan Siregar dengan aturan pidana sebagaimana yang termuat pada Pasal 352 ayat (2) Kitab Undang-undang Hukum Pidana yang pada pokoknya menjelaskan mengenai delik perbuatan secara kekerasan yang mengakibatkan luka berat yang mana dalam pasal ini dimana pelakunya adalah satu dimana dalam kasus yang diangkat dalam penelitian ini adalah satu orang pelakunya melakukan tindakan kekerasan terhadap saksi korban dalam melakukan penganiayaan yang menyebabkan luka berat

Selanjutnya sesuai dengan penjelasan Hakim Pengadilan Negeri Padangsidimpuan Aries Kata Ginting. SH apabila terjadi seperti kasus yang diangkat dalam penelitian ini dimana terdakwa Marhan Siregar dijatuhi dengan hukuman 2 tahun penjara hal ini disebabkan oleh satu orang saja yang melakukan kekerasan ataupun penganiayaan yang menyebabkan luka berat hal inilah penyebabnya Hakim dalam menjatuhkan hukuman yang berdasarkan Pasal 351 ayat (2) sebagaimana yang tedapat di dalam Kitab Undang-undang Hukum Pidana

Selanjutnya menurut pendapat Hakim yang telah disebutkan oleh penulis tersebut di atas juga mengatakan sesuai dengan pendapat salah seorang pakar hukum kita mengatakan apabila surat dakwaan diartikan sebagai surat atau akte yang memuat perumusan tindak pidana yang didakwakan kepada terdakwa, perumusan mana ditarik dan disimpulkan dari hasil pemeriksaan penyidikan dihubungkan dengan rumusan pasal tindak pidana yang dilanggar dan didakwakan pada terdakwa, dan surat dakwaan tersebutlah yang menjadi dasar pemeriksaan bagi Hakim dalam sidang pengadilan dan juga di dalam persidangan dimana 
Jaksa Penuntut Umum harusnya dapat membuktikan dalil-dalil yang dituntutnya terhadap seorang yang melakukan tindak pidana bak itu tindak pidana penganiayaan yang menyebabkan luka berat dan tindak pidana lainnya yang berkaitan dengan pembuatan sudart dakwaaan.

Umpanya seperti dalam kasus yang diangkat dalam penelitian ini yaitu tindak pidana penganiayaan yang menyebabkan luka berat yang mana terdakwanya satu orang dalam pemeriksaannya yang mana terhadap terdakwa Marhan Siregar dalam dakwaan Pertama melanggar Pasal 338 KUHP Jo Pasal 53 ayat (1) KUHP, Kedua Pasal 351 ayat (2) KUHP dan Ketiga Pasal 351 ayat (1) Kitab Undang-undang Hukum Pidana akan tetapi dalam Putusan Pengadilan Negeri Padangsidimpuan tersebut dimana Hakim telah mendengar keterangan para saksi-saksi yang diajukan dimuka persidangan dan telah didengar pulan keterangan terdakwa Marhan Siregar serta berdasarkan hasil Visum Et Repertum Projustita RSUD No. 440/49/VL/II/2015 tanggal 28 Februari 2015 an. AHMAD YANI HARAHAP yang ditanda tangani oleh dr. Indah Sari Harahap, maka dengan ini dimana Majelis Hakim Pengadilan Negeri Padangsidimpuan telah mempertimbangkan pula hal-hal yang memberatkan dan meringankan dan Mengingat, Pasal 351 ayat (2) Kitab Undang-undang Hukum Pidana, serta peraturan perundang- undangan yang berhubungan dengan perkara ini, maka sudah dapat dijatuhkan dengan hukuman 2 (dua) tahun penjara

\section{PENUTUP}

Penerapan hukuman terhadap pelaku tindak pidana penganiayaan yang menyebabkan luka berat disidang Pengadilan Negeri Padangsidempuan adalah harus berdasarkan fakta-fakta di persidangan dari keterangan saksi-saksi, keterangan terdakwa, alat bukti, dan alat bukti surat, menurut penulis Jaksa Penuntut Umum telah tepat dalam menetapkan dakwaan dan terdakwa terbukti telah melakukan tindak pidana penganiayaan yang menyebabkan luka berat yang memenuhi unsur-unsur sebagaimana yang terdapat dalam Pasal 351 ayat (1) Kitab Undangundang Hukum Pidana dimana terakwa Marhan Siregar telah dijatuhi dengan hokum penjara 2 (dua) tahun, menurut penerapan hukumannya sudah sesuai dengan apa yang terdapat di dalam peraturan perundang-undangan. 


\section{DAFTAR PUSTAKA}

Consevela G Sevilla, 1993, Metode Deskriptif, UI, Press, Jakarta

Departemen Kehakiman Republik Indonesia, 1981, Kitab Undang-undang Hukum Acara Pidana, Politeia, Bogor

Departemen Kehakiman Republik Indonesia, 1999, Undang-undang Hak Azasi $\quad$ Manusia, Jakarta

Gempur Sentosa, 2005, Metode Penelitian, Prestasi Pustaka Publisher, Jakarta

Laden Marpaung, 1986, Tindak Pidana Terhadap Nyawa dan Tubuh, Karya Anda, Surabaya

Moeljatno, 1983, Kitab Undang-undang Hukum Pidana, Bina Aksara, Jakarta

M. H, Tirtaamidjaja, 1955, Pokok-pokok Hukum Pidana, Fasco, Jakarta

Poerdarminto, 1992, Kamus Umum Bahasa Indonesia. Rajawali Press, Jakarta

R. Soesilo, 1993, Kitab Undang-undang Hukum Pidana Serta Komentar - komentarnya Lengkap Dengan Pasal Demi Pasal, Politeia, Bogor

R. Soesilo, 1979.Kitab Undang-undang Hukum Pidana, Politeia. Bogor

Satochid Kartanegara, 1989, Hukum Pidana Bagian I, Balai Lektur Mahasiswa, Medan

Sudarsono, 1998, Kamus Hukum, Pustaka Indonesia, Jakarta

Sudjana, 2008, Metodologi Penelitian, Sinar Grafindo, Grafindo, Jakarta

Sudarto,1997, Metodologi Filsafat, Raja Grafindo Persada

Tongat, 2008, Dasar - dasar Hukum Pidana Indonesia Dalam Perspektif Pembahasan. UMM. Pres Malang

Wirjono Projodikoro, 1998, Tindak-tindak Pidana Tertentu di Indoneia, Garuda Mas, Jakarta 